\title{
ALEX MODDEJONGE: Thirty Years of Big History
}

\author{
Correspondence | Alex Moddejonge, alexmoddejonge@gmail.com \\ Citation I Moddejonge, Alex. 2020. “Thirty Years of Big History.” Review of Origin Story: \\ A Big History of Everything, by David Christian. Journal of Big History 4 (3): 104-108. \\ DOI I https://doi.org/10.22339.jbh.v4i3.4370
}

B O OK R E V I E W

Christian, D. 2019. Origin Story: A Big History of Everything. New York: Little, Brown and Company.

2019 was big year for Big History: it marked three decades since David Christian's inaugural course at Macquarie University. Arriving just in time for the anniversary is Christian's latest work, Origin Story: A Big History of Everything. Featuring a splashy endorsement from Bill Gates splashed on the cover, Origin Story accomplishes several goals simultaneously. Even reviewers who have criticized the book freely admit that the book amounts to "an impressive act of authorial chutzpah" that deserves admiration (Weiner). If nothing else, Origin Story also operates as an extremely effective "short course in modern science" for non-specialists (Wooton). Most obviously, it works as a revision and update of Christian's monumental monograph Maps of Time: An Introduction to Big History (2004). Christian inserts a wealth of new findings gleaned from the past fifteen years, specifically in the early chapters on cosmology and biology. For example, Christian notes Einstein's formulation that gravity generated waves of energy was finally validated by the Laser Interferometer Gravitational-Wave Observatory in 2015. He, likewise, cites a 2017 discovery from Northern Quebec, which suggests life might have appeared on Earth as early as $\mathbf{4 . 2}$ billion years ago.

This tantalizing possibility seems to have compelled Christian to reconfigure the Big History narrative slightly. In Maps, the Earth's geological processes are described prior to the appearance of life. However, the suggestion that life sprang up several hundred million years earlier than pre- viously believed has pressed Christian to look at geology as potential generator of the first organisms. For this reason, he opts to depict geology as an adjunct to his chapters on biology rather than planet-formation. It is a subtle but important shift that helps develop the Big History narrative toward true cross-disciplinary integration-assuming it can be verified.

Beyond updating the narrative, Origin Story also works a distillation Big History for readers of popular non-fiction. Like a film script that successfully compresses characters and plot development, the shorter breadth of this volume allows Christian the opportunity to pare down the manuscript of Maps to a comparatively breezy 357 pages (including endnotes and index). Gone, too, are the many tables, timelines, and maps that populate the previous book. Out as well are Christian's detailed appendices on dating techniques and an examination of order vs. chaos. In their place is a two-page timeline, one page of statistics on human history, and a helpful glossary of Big History terms. As a work of simplicity, Origin Story also succeeds as an update on the late Cynthia Stokes Brown's Big History: From the Big Bang to the Present (2007) in terms of offering a comparatively straight-forward crash course on the subject for beginners.

On a conceptual basis, Origin Story continues Christian's use of the principle of emergence in complex structures as basic historical thresholds. These thresholds in turn serve as chapter breaks that separate the Big History narrative into ma- 
nageable chunks. Christian identifies nine, starting with the Big Bang and ending with an as-yetunrealized sustainable world order. In defining these thresholds, Christian also deploys his metaphor of scales, comparing phenomena at one scale to another. For instance, he points out that densely populated villages resembled the same "clumps of matter" out of which early stars were formed. At another point Christian describes how the Mesopotamian elite pumped wealth into new urban areas through a mix of persuasion and coercion of their peasant populations, "like the proton pumps that maintain an energy gradient across cell membranes..." (221). Later, he playfully describes Fritz Haber and Carl Bosch as "the first multicellular organisms to successfully fix atmospheric nitrogen" (264). One interesting comparison that Christian does not make is between human history and the overall history of life. He might have pointed out that only a tiny sliver of human history comprises the agrarian and industrial eras, just as only a small percentage of the history of life encompasses the era of multicellular, big life. Such a comparison would reinforce one of the general themes in Origin Story: that simple structures endure more successfully than complex structures.

Christian employs other literary devices worth noting, including the use of vivid tableaux to illustrate his themes. One is that of orbiting aliens as silent witnesses to the complex changes on planet Earth. Christian, making either a conscious or unconscious nod to the god-like extraterrestrials of 2001 or the Tralfamadorians of Slaughterhouse Five, uses these silent sentinels to speculate on the seeming randomness of many historical events-of which the appearance of humankind in the biosphere and its eventual domination over said biosphere is perhaps the most unexpected outcome of all.

Otherwise, Christian continues the Bill Bryson -method of sprinkling in scientific anecdotes to flavor some of the drier scientific discoveries that inform the pre-human narrative. Who can think about the discovery of cosmic microwave background radiation (CMBR) without remembering the pigeons roosting in the antenna at Bell Labs? Sadly, this motif does not carry over to the chap- ters on human history. To create a more coherent hyper-narrative, it might have been helpful to describe some of the schools of historical thought that he relied on to tell the story of agrarian and industrial civilizations. Without similar examples, the Big History narrative runs the risk of sounding like received knowledge rather than formulated wisdom. A bibliographic appendix the historiography would have been a useful addition.

Now for a few minor issues regarding conceptualization. As compressed as Christian has made Big History, he still spends an inordinate amount of time (an entire chapter!) on the origins of farming and another chapter on pre-modern agrarian civilizations. (Maps also contains a chapter devoted solely to the advent of agriculture.) A single chapter on both phenomena would have made the work even more concise, in the same way he integrated geology and biology. In his chapter on the future, Christian has likewise dropped the Rapa Nui as the this-island-earth metaphor used in Maps. Instead, he discusses the relative merits of the Good and Bad Anthropocene, and how to preserve the former while phasing out the destructive features of the latter. This section is more didactic and less vivid than the historical example of Easter Island. The reason Christian jettisoned it is likely due to historical controversy about the demographic collapse of the island's native inhabitants. The caravan metaphor used to describe individual humans' lives in introduction to Maps has also been replaced by a cavalcade in Origin Story but serves the same function.

Another rhetorical device that bears examination is Christian's tendency to anthropomorphize the aspects of the universe. Heat energy, for example, is described as a "drunken traffic cop" who "directs energy every which way and creates chaos" (42). For this reason, Big History terms like complexity and entropy are transformed into almost godlike entities imbued with human characteristics. While Christian the writer should be praised for making his history lively, the choice in writing style runs the risk of turning physical phenomena into cosmic entities in the minds of general readers. 
At the same time, Christian chooses numerous descriptive nouns with dubious connotations, particularly when it comes to human activities and institutions. For instance, the first Sumerian city-state, Uruk, is referred to as a "monster" and the spread of farming across Eurasia as a "virus" (a debatable characterization since farming also emerged independently in many other areas of the world). Again, this is likely done to make the text more relatable and entertaining to casual readers. However, the choice of these types of words make it hard for said readers to come away from Origin Story without the view that farming, urbanization, and finally industrialization were all net negatives due to their effect on the biosphere and the quality of human life.

Perhaps, the most important matter is the intent of Big History as conceptualized by Christian. The quasi-religious theme of creation myths in Maps has been traded in for the quasistorytelling theme of Origins. No doubt, this came as a result of criticism Christian received for the seemingly contradictory endeavor of rendering a scientific history in mythological terms. However, replacing creation myths with origin stories accomplishes almost nothing new conceptually because the two are essentially interchangeable in the way Christian describes them. Though Christian insists that "like all origin stories," Big History "will never lose a sense of mystery and awe," the scientific neutrality of Origin Story would seem to preclude this (Christian 10). Eliminating the mystery and eschatologythemselves remnants of the premodern, preEnlightenment human conceptions of realityshould be the entire point of the Big History project. On a purely psychological level, Origin Story aims at mitigating "the sense of disorientation, division, and directionlessness ... . everywhere in today's world" (8). Christian thus sets up Big History as the answer to modern humanity's malaise and ennui. Even if there is a gap to be filled, is that the purpose of Big History or simply a byproduct of it?

Historian David Wooten, whom Christian cites in his text, has criticized Origin Story on slightly different grounds. While Wooten concedes that humans' desire an origin story, he believes Chri- stian "makes a basic error" in the way he uses the concept. "We crave origin stories because we want to know that our existence has meaning. But the story Mr. Christian tells us is one that shows our existence to be without any meaning at all" (Wooton). Another reviewer has reinforced this critique, noting that the power of creation myths is that they "supply meaning in an otherwise meaningless universe, even if they fall short on facts" (Weiner). What these critics seem to be ignoring is that the implied meaning inherent in complexity theory does elevate the human experience. This is what is suggested by Christian's assertion that the Big History project represents the universe "slowly opening an eye after a long sleep" (5). While this is yet another anthropomorphic description, this time it is thoroughly appropriate. If the eye is opening, it is because of humankind. In other words, humanity is the eye.

In the search for a meaning (or at least a moral order) Christian has latched on to the centrality of environmentalism. In Christian's narrative, humanity is important in as much as it acts as responsible custodians of the biosphere. How humanity acts in the short-term future in relation to the environment is referred to as "the quest." The quest is the meaning that can be derived from the universe opening its eye and only the scale of Big History can help "prepare us for the huge challenges and opportunities that all of us face at this pivotal movement in the history of planet earth" (10). The goal of the quest is to avoid an environmental crash since "there is no good place for humans in a ruined biosphere" (290). Christian describes the lofty goals set forth in the 2015 United Nations document "Transforming Our World" as the next step in this journey. Reaching back to the play of scales, the author hopes humanity will imitate the sun and "settle into a period of dynamic stability" (Christian 294). He notes, however, that such an outcome "will depend to some extent on how well and how persuasively people can describe the quest itself" (300). In other words, it depends upon how successful the Big History project is in seeping into the public psyche in order to influence policy designs.

The sustainability argument is augmented by quotes from figures of the Western intelligentsia 
as diverse as John Stuart Mill and Robert Kennedy, both of whom made comments supporting what became fashionably known in the 1970s as "limits to growth." The pervasive thought patterns of that decade, including concerns of unchecked population growth and environmental degradation, have inextricably shaped Christian's worldview and inform his approach to Big History in the twenty-first century. The potential problem is that this may reduce Big History to a political talking point-one that appeals less to Lagos and Mumbai, and more to Davos and Berkeley. As Christian notes in his introduction, "Many of the pieces of our origin story fell into place during my lifetime" (4). This makes the Big History narrative a story as much about its author as about the universe itself.

In considering the future, Christian refers to the present global environmental situation as "the slow-motion time of a near accident." He also asserts that humanity is "now managing an entire biosphere, and we can do it well or badly" (289). As with the spiritual and psychological need for Big History, this assertion must be met with a dash of cynicism. While we are certainly influencing the biosphere more than any other organism, are humans exerting more power than, say, plate tectonics? Even if this were the case, there is a vast difference between influence and management. Then the larger question becomes whether the goal of humanity is to survive as a species or sustain the biosphere. Christian believes the two are inextricably intertwined. One might just as easily argue that a better quest could be a longer-range goal that allows humans to escape the confines of the biosphere via accelerated technological advances in transhumanism or space travel.

Christian's sustainability ethos is also characterized in his continuing romance with paleolithic human societies. In addition to recycling Marshall Sahlins' the original affluent society thesis concerning foragers, Christian depicts them as living in relative harmony with the natural world. However, this image is directly contradicted by practices such as big game hunting and firestick farming, both of which Christian details. Despite this, in his concluding chapter on the future,
Christian states "What it means to live richly and dynamically in a less changeable world is preserved within the cultures of many modern indigenous communities whose people see themselves primarily as custodians of a world larger and older than themselves" (294). While this reinforces the cyclical appeal of Big History as something that reaches back into the deep past of the human imagination, to what extent can foraging societies really inform of a world of 7.8 billon people about sustainability?

Another contradiction comes in the introduction, where Christian argues that "[w]e should not make the mistake of assuming that complex things are necessarily better than simple things" (11). However, in the universe described by Big History, greater complexity is always going to be inherently more relevant and more interesting. Without increasing complexity there would be no historical development. Christian also asserts a potentially misplaced belief that "accelerating change" will lead inevitably to a "catastrophic explosion -the human equivalent, perhaps, of a supernova" (300). One could just as easily argue that the "goal" of humanity should be to increase complexity in the universe (contra entropy) rather than top it off. While it is true that the modern revolution has provided "a growing awareness that we humans share a common fate on our one home, planet Earth" (299), it is not inevitable that we shackle ourselves to such a fate. In any event, attempting to "manage" such a future seems unlikely, considering our past. Wooten takes this even further, concluding that Christian's project is "a futile enterprise. His origin story does not give meaning to our lives; and his environmentalism is based on incorrigible wishful thinking, on the belief that we can come to behave like a close-knit, well-intentioned, rational community-all history suggests that this will never happen" (Wooton).

Christian describes Big History as "the first origin story to embrace human societies and cultures from around the world" (x). Later he insists it "has been built not by a particular region or culture but by a global community of more than seven billion people, so it pools knowledge from all parts of the world" (9). However, these claims are 
contradicted by the admission that Big History emerged from the "dynamic and potentially destabilizing tendencies of modern capitalism" (10). Big History is thus an outgrowth of what used to be referred to as Western Civ., and yet one of Christian's most powerful images is his imagined scene of ancient Australian aboriginals exchanging origin/creation stories around the campfire. This works as a stand-in for the potential unification of humanity itself through the unification of knowledge. This is a powerful and important message, particularly in the hyper-partisan atmosphere of today's world. Liberals and conservatives do not merely disagree on the issues: they disagree on the nature of reality itself. An apolitical, truly global Big History can have the potential to bridge this divide. If Big History is to grow, it must.

Ultimately, the Big History narrative still exhibits many gaps in what science can adequately explain about the roots of complex structures. As Weiner notes, Origin Story "contains plenty of mystery. . . on a cosmic scale." Perhaps there is still too much mystery. He asks, "Why does the universe contain any structure at all and not just a random flux of energy? Why did the agrarian revolution erupt almost simultaneously in places separated by thousands of miles?" (Weiner) The precise origins of life on Earth and collective learning in Homo sapiens remain unclear. Christian reasons that life is the natural outcome of complex chemical reactions and suggests viruses as a possible link, but this is only informed speculation. The reason the Big Bang occurred is even more inscrutable and perhaps unknowable. In order to try to offer an explanation, Christian ends Origin Story by alluding to the multiverse, a concept that at this point is still pseudo-scientific speculation. It would be easier to say "We don't know," but that would also be far less satisfying.

\section{References}

Christian, D. 2019. Origin Story: A Big History of Everything. New York: Little, Brown and Company.

Weiner, E. 2018. "In This Origin Tale, Humans and Amoebas Get Equal Billing." Washington Post,
The, (June 22). http://libcatalog.atu.edu:2062/ login.aspxdrect=true\&db=nfh\&AN=wapo.

5258cod6-577c-11e8-

8836a4a123c359ab\&site=ehost-live\&scope $=$ site. Wootton, D. 2018. "'Origin Story' Review: The View from Above; They Call It 'Big History': An Attempt to Stitch All of Earth's Past into One Global Narrative." Wall Street Journal, (May 18) (Online) Retrieved from https:// www.wsj.com/articles/origin-story-review-theview-from-above-1526592346. 